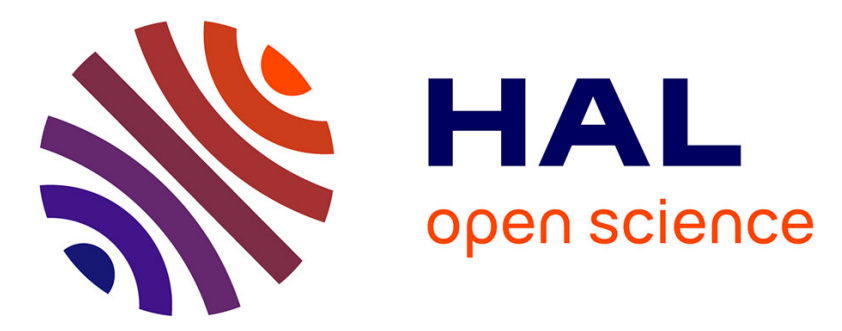

\title{
Localization of salmon gonadotropin releasing hormone mRNA and peptide in brain of atlantic salmon and rainbow trout
}

T. Bailhache, A. Arazam, H. Klungland, P. Alestrom, Bernard Breton, P. Jego

\section{- To cite this version:}

T. Bailhache, A. Arazam, H. Klungland, P. Alestrom, Bernard Breton, et al.. Localization of salmon gonadotropin releasing hormone mRNA and peptide in brain of atlantic salmon and rainbow trout. Journal of Comparative Neurology, 1994, 347, pp.444-454. 10.1002/cne.903470310 . hal-02715916

\section{HAL Id: hal-02715916 \\ https://hal.inrae.fr/hal-02715916}

Submitted on 1 Jun 2020

HAL is a multi-disciplinary open access archive for the deposit and dissemination of scientific research documents, whether they are published or not. The documents may come from teaching and research institutions in France or abroad, or from public or private research centers.
L'archive ouverte pluridisciplinaire HAL, est destinée au dépôt et à la diffusion de documents scientifiques de niveau recherche, publiés ou non, émanant des établissements d'enseignement et de recherche français ou étrangers, des laboratoires publics ou privés. 


\title{
Localization of Salmon Gonadotropin-Releasing Hormone mRNA and Peptide in the Brain of Atlantic Salmon and Rainbow Trout
}

\author{
THIERRY BAILHACHE, AÏCHA ARAZAM, HELGE KLUNGLAND, \\ PETER ALESTRÖM, BERNARD BRETON, AND PATRICK JEGO \\ Laboratoire de Physiologie des Régulations, Université de Rennes 1, Campus de Beaulieu, \\ 35042 Rennes Cedex, France (T.B., A.A., P.J.); Department of Dairy and Food Industries, \\ Agricultural University of Norway, N-1432, ÅS NLH, Norway (H.K., P.A.); Laboratoire de \\ Physiologie des Poissons, INRA, Campus de Beaulieu, 35042 Rennes Cedex, France (B.B.)
}

\begin{abstract}
The decapeptide gonadotropin-releasing hormone $(\mathrm{GnRH})$ is a key hormone for the central regulation of reproduction. The distribution of salmon GnRH (sGnRH), which is the major form in salmonids, has been studied in different fish species by immunocytochemistry. Discrepancies in data concerning the distribution of $\mathrm{sGnRH}$ perikarya led us to investigate this problem in two species, the Atlantic salmon and the rainbow trout, with in situ hybridization of sGnRH messenger, a highly specific molecular tool. By Northern blot analysis, the rainbow trout sGnRH messenger appears to be about 500 bases in length, which is close to those isolated from Atlantic salmon or masu salmon and characterized previously. In situ hybridization with riboprobes generated with Atlantic salmon sGnRH cDNA demonstrated that sGnRH perikarya are restricted to the ventral part of olfactory bulbs, telencephalon, and preoptic area. They are distributed on a nearly continuous line extending from the olfactory bulbs to the preoptic area in both salmonid species studied.

Despite the presence of GnRH-like immunoreactivity in the preoptic magnocellular nucleus (NPOm) and in the tegmentum of the midbrain (MT), the sGnRH mRNA is not present in these two structures. Stained cells in NPOm could be target cells for GnRH and immunoreactive neurons in MT are likely to be chicken GnRH-II containing cells. Our study not only gives a precise distribution of the sGnRH system in two salmonids, Atlantic salmon and rainbow trout, but also clarifies the ambiguous data published up to now in rainbow trout. 1994 Wiley-Liss, Inc.
\end{abstract}

Key words: salmon gonadotropin-releasing hormone, in situ hybridization, immunocytochemistry, Salmo salar, Oncorhynchus mykiss

Gonadotropin-releasing hormone $(\mathrm{GnRH})$ plays a major role in the regulation of the hypothalamic-pituitarygonadal axis leading to the control of reproductive events. The structure of this decapeptide has been studied in a wide variety of vertebrates, and up to eight different forms have been identified among all classes (Sower et al., 1993). In salmonids, two molecular forms of GnRH have been characterized: salmon GnRH (sGnRH; Sherwood et al., 1983) and chicken GnRH-II (cGnRH-II; Sherwood et al., 1986). These two forms are present together in the same fish but appear to have different patterns of distribution in the brain (Amano et al., 1991). The sGnRH that is the major form in salmonids (Sherwood et al., 1984) is widely distributed in the brain and pituitary, whereas the cGnRH-II is undetect- able in the olfactory bulbs and pituitary (Okuzawa et al., 1990; Amano et al., 1992), suggesting that the latter form does not directly participate in the control of pituitary functions.

The distribution of GnRH-containing cells has been studied by immunocytochemistry in a number of salmonids, but all observations are not in agreement. A possible explanation for such a discrepancy in data could be the specificity of the antisera used in these studies. For in-

\footnotetext{
Accepted March 10, 1994
}

Address reprint requests to Dr. T. Bailhache, Laboratoire de Physiologie des Régulations, URA CNRS 256, Université de Rennes 1, Campus de Beaulieu, 35042 Rennes Cedex, France. 
stance, in the rainbow trout, three studies have been performed with antisera directed against mammalian $\mathrm{GnRH}$ $(\mathrm{mGnRH})$. One did not reveal any immunoreactive (ir) cell bodies (Dubois et al., 1979), whereas the others found GnRH-ir perikarya either in the dorsal telencephalon (Goos and Murathanoglu, 1977) or in the preoptic magnocellular nucleus (NPOm; Shäffer et al., 1989). By contrast, when studies were conducted with antisera against salmon GnRH, immunoreactive perikarya were found to be distributed in the ventral part of the olfactory bulbs, telencephalon, and preoptic area (Breton et al., 1986; Amano et al., 1991).

Because the preoptic area is usually considered to be one of the most important areas in the fish brain for the control of reproduction (for review, see Peter and Fryer, 1983), it was necessary to perform experiments with sensitive and highly specific molecular tools. Therefore, to investigate further the sGnRH system in salmonids, we have developed an in situ hybridization method to detect sGnRH mRNA in brain sections, using an sGnRH cDNA cloned from Atlantic salmon (Klungland et al., 1992b). In fact, one study has been conducted with such a technique in the masu salmon (Suzuki et al., 1992), but the authors did not compare their results with immunocytochemical data on preoptic sGnRH neurons.

In the present paper, we describe the distribution of sGnRH expressing perikarya in two salmonids, the Atlantic salmon and the rainbow trout. For the latter, results of in situ hybridization are compared with immunocytochemical data of sGnRH.

\section{MATERIALS AND METHODS Animals}

Three-year-old Atlantic salmon (Salmo salar) weighing 2-3 kg, transferred to fresh water for 1 month, and 2-year-old rainbow trout (Oncorhynchus mykiss), weighing $1.5-2.0 \mathrm{~kg}$, kept in fresh water, were used in this study. All fish used were females at the end of vitellogenesis, as determined by oocyte diameter $(4-5 \mathrm{~mm})$ and were purchased from an experimental fish farm (SEMI, France). Five females of each species were used for in situ hybridization (ISH), and immunocytochemistry (ICC) was performed on five female rainbow trout.

\section{Abbreviations}

$\begin{array}{ll}\text { AC } & \text { anterior commissure } \\ \text { C } & \text { cerebellum } \\ \text { Dm } & \text { area dorsalis telencephali pars medialis } \\ \text { HA } & \text { habenula } \\ \text { ICL } & \text { internal cell layer (granule cell layer) } \\ \text { M } & \text { medulla oblongata } \\ \text { MT } & \text { tegmentum of the midbrain } \\ \text { NAPv } & \text { nucleus anterioris periventricularis } \\ \text { NE } & \text { nucleus entopeduncularis } \\ \text { NPOm } & \text { nucleus preopticus pars magnocellularis } \\ \text { NPOp } & \text { nucleus preopticus pars parvicellularis } \\ \text { NPP } & \text { nucleus preopticus periventricularis } \\ \text { OB } & \text { olfactory bulb } \\ \text { OC } & \text { optic chiasma } \\ \text { ON } & \text { olfactory nerve } \\ \text { OT } & \text { optic tectum } \\ \text { Pit } & \text { pituitary } \\ \text { SV } & \text { saccus vasculosus } \\ \text { T } & \text { telencephalon } \\ \text { Vd } & \text { area ventralis telencephali pars dorsalis } \\ \text { Vl } & \text { area ventralis telencephali pars lateralis } \\ \text { Vv } & \text { area ventralis telencephali pars ventralis }\end{array}$

\section{Northern blot analysis}

Total RNA was extracted from 20 rainbow trout brains by a lithium chloride/urea method (Auffray and Rongeon, 1980) and messenger RNAs (poly- $A^{+}$) were purified on an oligo(dT) trisacryl column as described by Aviv and Leder (1972).

Poly- $\mathrm{A}^{+}$mRNAs were run on a formaldehyde-agarose denaturing gel and transferred to a nylon membrane (Biodyne, Pall). The membrane was hybridized under highstringency conditions (Thomas, 1980) with $\alpha^{32} \mathrm{P}$-labeled sGnRH cDNA and autoradiographed with a Kodak X-Omat film.

\section{Tissue fixation}

Fish were deeply anaesthetized in phenoxy ethanol (Merck; $4 \mathrm{ml} / 10$ liters fresh water) and kept under gill perfusion with the same solution. They were perfused through the heart with $100 \mathrm{ml}$ heparin (Roche; $10 \mathrm{UI} / \mathrm{ml}$ ) in phosphate-buffered saline (PBS; $137 \mathrm{mM} \mathrm{NaCl}, 2.6 \mathrm{mM}$ $\mathrm{KCl}, 8 \mathrm{mM} \mathrm{Na} \mathrm{HPO}_{4}, 1.5 \mathrm{mM} \mathrm{KH}{ }_{2} \mathrm{PO}_{4}, \mathrm{pH}$ 6.8) for ISH, or in phosphate buffer (PB; $0.1 \mathrm{M}, \mathrm{pH} 7.2$ ) for ICC, followed by $500 \mathrm{ml}$ fixative (paraformaldehyde $4 \%$ in the respective buffer). Brains were removed from the skull and postfixed overnight at $4^{\circ} \mathrm{C}$ in the fresh fixative.

\section{In situ hybridization}

In situ hybridization was performed according to Wilkinson et al. (1987), a method adapted to fish brain by Salbert et al. (1991). Briefly, after two rinses in PBS and saline $(0.9 \% \mathrm{NaCl})$, brains were dehydrated and embedded in paraffin wax. Parasagittal sections ( $6 \mu \mathrm{m}$ thick) were cut with a microtome and transferred to 3-amino-propyltriethoxysilane (Sigma, St. Louis, MO) coated slides and stored at $4^{\circ} \mathrm{C}$ with silica gel. After removal of the wax, sections were rehydrated in saline, postfixed in $4 \%$ paraformaldehyde in PBS, treated with proteinase $\mathrm{K}(20 \mu \mathrm{g} / \mathrm{mI}$ in $50 \mathrm{mM}$ Tris $\mathrm{HCl}, 5 \mathrm{mM}$ EDTA, pH 8.0), fixed again in the same fixative, and immersed in acetic anhydride $0.25 \%$ in triethanolamine $0.1 \mathrm{M}, \mathrm{pH} 8.0$ ). One rinse in PBS was made between each step. Sections were then dehydrated through an ethanol series and air dried.

Hybridization was performed with $\alpha\left[^{35} \mathrm{~S}\right] \mathrm{UTP}$-labeled riboprobes synthesized with sGnRH cDNA (Klungland et al., 1992b) cloned in pGEM 7 (Promega). Labeled sense and antisense probes were obtained from the linearized construct using T7 and SP6 polymerase (Boehringer), respectively (specific activity was $2 \times 10^{9} \mathrm{cpm} / \mu \mathrm{g}$ ). Because short, single-strand RNA probes increase the specific signal (Angerer and Angerer, 1981), [ ${ }^{35}$ S]UTP-labeled riboprobes were trimmed to an average length of 100 nucleotides (Cox et al., 1984). Two nanograms of labeled probe was distributed on each slide in $20 \mu$ l hybridization mix [ $50 \%$ deionized formamide, $0.3 \mathrm{M} \mathrm{NaCl}, 20 \mathrm{mM}$ Tris $\mathrm{HCl}, \mathrm{pH} 8.0,5 \mathrm{mM}$ EDTA, 10\% dextran sulfate, $1 \times$ Denhardt's solution, 10 $\mathrm{mM}$ dithiothreitol (DTT), and $0.5 \mathrm{mg} / \mathrm{ml}$ yeast RNA]. Slides were covered with coverslips, and hybridization was carried out overnight at $50^{\circ} \mathrm{C}$ in a moist chamber.

After high-stringency washes $(50 \%$ formamide, $0.3 \mathrm{M}$ $\mathrm{NaCl}, 30 \mathrm{mM}$ sodium citrate, $10 \mathrm{mM} \mathrm{DTT}, \mathrm{pH} 7.2$, at $65^{\circ} \mathrm{C}$ ) and RNase treatment $(20 \mu \mathrm{g} / \mathrm{ml}$ in Tris-EDTA buffer), sections were dehydrated, immersed in Ilford K5 nuclear track emulsion, and autoradiographed for 10-15 days at $4^{\circ} \mathrm{C}$. Slides were developed (Kodak D-19), fixed in $\mathrm{NaS}_{2} \mathrm{O}_{3}$ 
(30\%), counterstained with toluidine blue $(0.02 \%)$, and mounted with Depex (Gurr).

\section{Immunocytochemistry}

Immunocytochemistry of sGnRH was performed in rainbow trout with a standard peroxidase-antiperoxidase (PAP) procedure on free-floating sections. After fixation, brains were rinsed in $\mathrm{PB}$ and placed in $12 \%$ sucrose in $\mathrm{PB}$ for 6 hours at $4^{\circ} \mathrm{C}$. They were frozen on dry ice and cut with a cryomicrotome. Parasagittal or frontal sections $(50 \mu \mathrm{m}$ thick) were collected, rinsed in $\mathrm{PB}$, treated with $0.3 \% \mathrm{H}_{2} \mathrm{O}_{2}$ in $\mathrm{PB}$, incubated with $10 \%$ lysine in $\mathrm{PB}$ containing $1 \%$ normal sheep serum, and finally incubated overnight at $4^{\circ} \mathrm{C}$ in the primary antiserum (rabbit anti-sGnRH, dilution $1 / 2,000$ in $\mathrm{PB}$ containing $0.1 \%$ triton).

According to the PAP technique, sections were incubated with goat serum antirabbit immunoglobulins (Jackson; $1 / 200$ in PB) for 1 hour and then in the PAP complex (Dako; 1 /400 in PB) for 1 hour. Extensive rinses were made between each step. The peroxidase was finally revealed by a 10 minute incubation with $0.025 \%$ diaminobenzidine and $0.02 \% \mathrm{H}_{2} \mathrm{O}_{2}$ in $0.04 \mathrm{M}$ Tris $\mathrm{HCl}, \mathrm{pH} 5.5$. Sections were put on gelatin-coated slides, dehydrated, and mounted with Depex.

The specificity of the primary antibody has been previously described (Breton et al., 1984). The following controls were used: 1) omission of the primary antibody, 2) replacement by a nonimmune rabbit serum, and 3) preadsorption with synthetic sGnRH.

\section{Data analysis}

Parasagittal and frontal sections, taken at different levels of the brain, were drawn under a microscope with a camera lucida (objective $\times 4$ ), and sGnRH-expressing perikarya or ir neurons were reported on these drawings based on the observation of several sections coming from different fish. Brain structures were also outlined with the help of counterstained sections and according to the nomenclature of Billard and Peter (1982).

\section{RESULTS \\ Northern blot analysis}

Northern blot hybridization of poly- $\mathrm{A}^{+}$mRNA from vitellogenic rainbow trout with $\mathrm{sGnRH}$ cDNA revealed a single band corresponding to a messenger approximately 500 bases long (Fig. 1). This result obtained under highstringency conditions shows that the cDNA can be used for in situ hybridization studies in Atlantic salmon as well as in rainbow trout.

\section{In situ hybridization in Atlantic salmon}

The background noise observed with the control sense probe was very low (Fig. 3D) and similar to the signal obtained with antisense probe over tissue that did not express sGnRH. Labeled sGnRH neurons were detected by the accumulation of dense silver grains in the cellular body, and sometimes this labeling was also seen in the initial part of primary dendrites (Fig. 3C).

Perikarya revealed by the antisense probe were scattered in the ventral part of the following areas: olfactory bulbs, telencephalon, and preoptic area (Fig. 2). Labeled neurons were fusiform or bipolar, and most of them were oriented rostrocaudally.

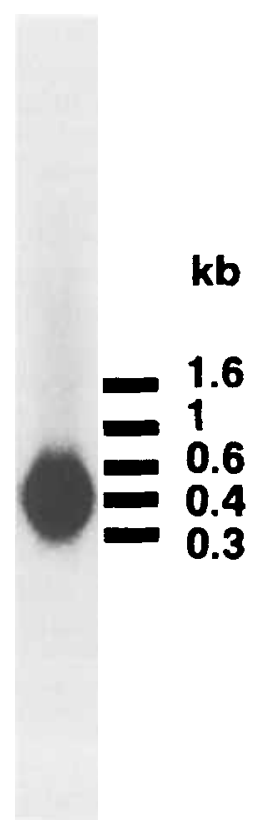

Fig. 1. Northern blot analysis of salmon gonadotropin-releasing hormone ( $\mathrm{sGnRH}$ ) mRNA in rainbow trout. Five milligrams of poly-A mRNA purified from the telencephalon and transferred to a nylon membrane (Biodyne, Pall) was hybridized with $\alpha^{32} \mathrm{P}$-labeled sGnRH cDNA probe and washed under high-stringency conditions. The membrane was autoradiographed for 48 hours at $-80^{\circ} \mathrm{C}$.

The most rostral labeled perikarya were located in the olfactory bulbs (Fig. 3A) and appeared to project into the olfactory nerves. Numerous sGnRH cells were located at the junction between the telencephalon and the olfactory bulbs (Fig. 3C). The highest density of sGnRH neurons was observed in this structure. Labeled cells in the ventral telencephalon were scattered close to the meninges. In the preoptic area, the labeled cells were found in the ventral part of the nucleus preopticus periventricularis (NPP; Fig. $3 \mathrm{~B})$ or in the ventrolateral part of the preoptic nucleus (NPO) and nucleus anterioris periventricularis (NAPv).

We did not observe any labeled cell in the NPOm. Neither did we observe any labeled cell caudally to the preoptic area in the other structures studied, including the tegmentum of the midbrain (MT) and the hypothalamus.

\section{In situ hybridization in rainbow trout}

The labeling of sGnRH perikarya was less intense in the rainbow trout (Fig. 5) than in Atlantic salmon (Fig. 3), although the overall distribution of $\mathrm{sGnRH}$-expressing neurons in the rainbow trout was similar (Fig. 4). Labeled neurons were scattered in the ventral part of olfactory bulbs, ventral telencephalon, and ventral preoptic area (Fig 5 ). We did not observe any silver grain accumulation in NPOm and MT neurons.

\section{Immunocytochemistry in rainbow trout}

sGnRH-ir cells were widely distributed in all brain regions studied (Fig. 6). Most of the ir cell bodies were found scattered along a nearly continuous line extending ventrally from the olfactory nerves to the preoptic area, but ir perikarya were also observed in $\mathrm{MT}$.

Immunoreactive neurons were observed in the ventral part of the olfactory bulbs (Fig. 7A). Some of the ir 


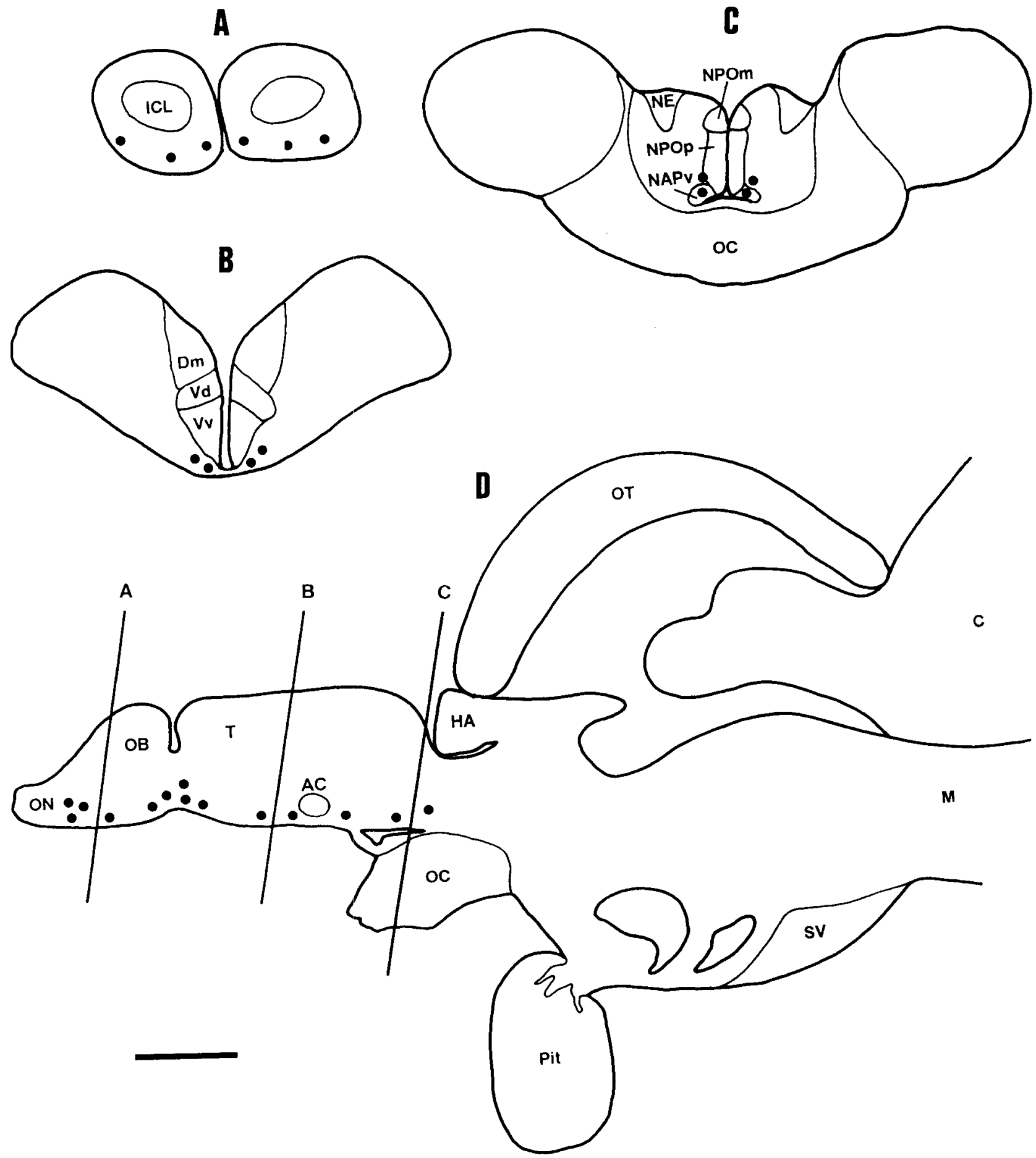

Fig. 2. Distribution of $\mathrm{sGnRH}$ mRNA-containing perikarya as revealed by in situ hybridization in the brain of Atlantic salmon. Frontal sections at the level of the olfactory bulbs $(\mathbf{A})$, telencephalon $(\mathbf{B})$, and preoptic area $(\mathbf{C})$ and overall representation in the sagittal plane $(\mathbf{D})$. Scale bar $=1 \mathrm{~mm}$.

perikarya found in the rostral part of the olfactory bulbs close to the olfactory nerves have their processes running rostrally into these nerves. Most of them were bipolar and oriented rostrocaudally. This group of neurons extended caudally up to the junction between the olfactory bulbs and the telencephalon, where we found the greatest density of GnRH perikarya (Fig. 7B).

In the telencephalon, ir perikarya were found scattered in the ventral part of the brain, close to the meninges. They were bipolar and elongated in shape (Fig. 7C). Numerous ir 

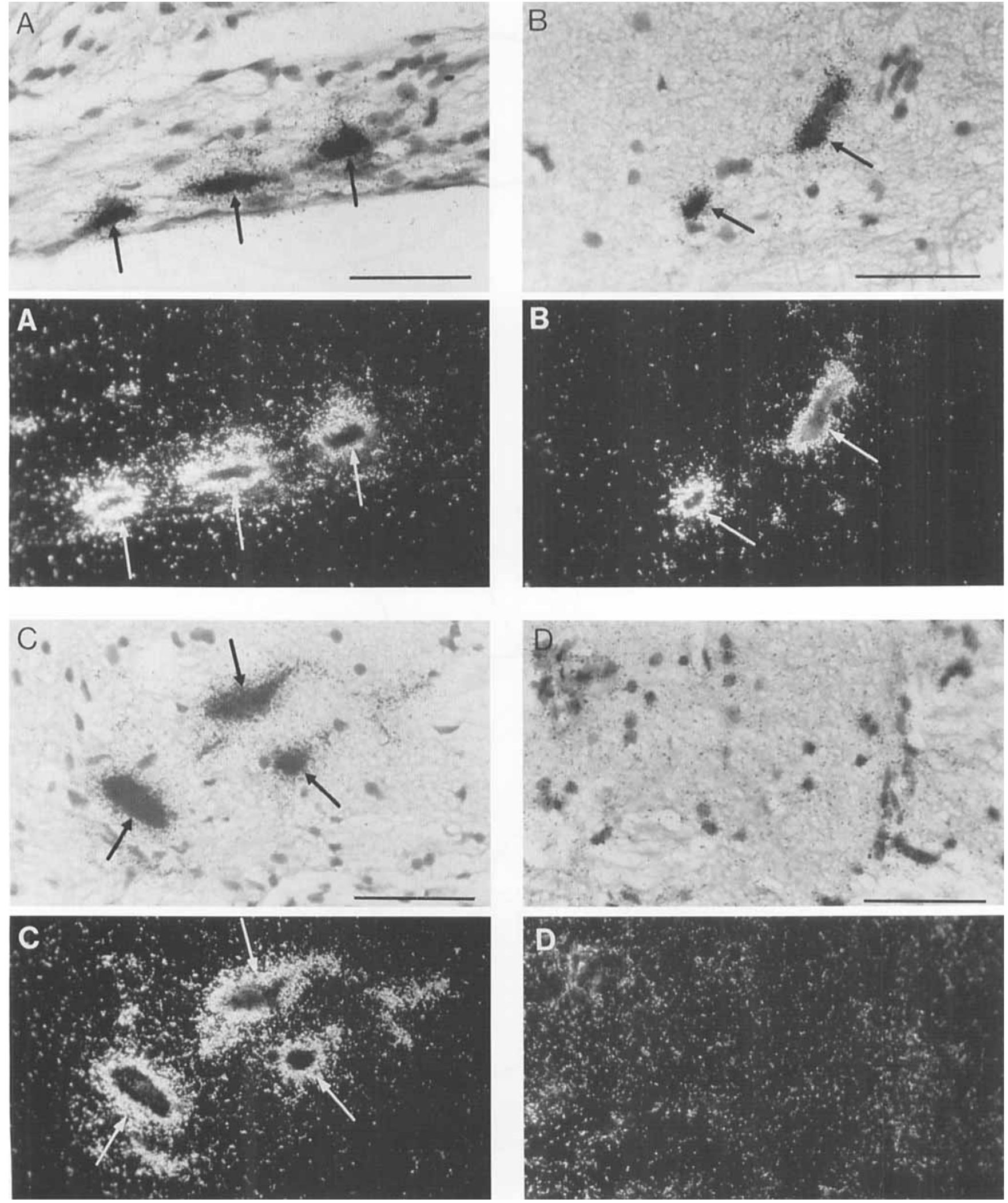

Fig. 3. Brightfield (top) and darkfield (bottom) photomicrographs of sGnRH mRNA-containing cells in Atlantic salmon. Labeled cell bodies (arrows) were observed in the olfactory bulbs (A), telencephalon (C), and ventral preoptic area (B). The control sense probe gave the background signal (D: section adjacent to C). Scale bar $=50 \mu \mathrm{m}$. 


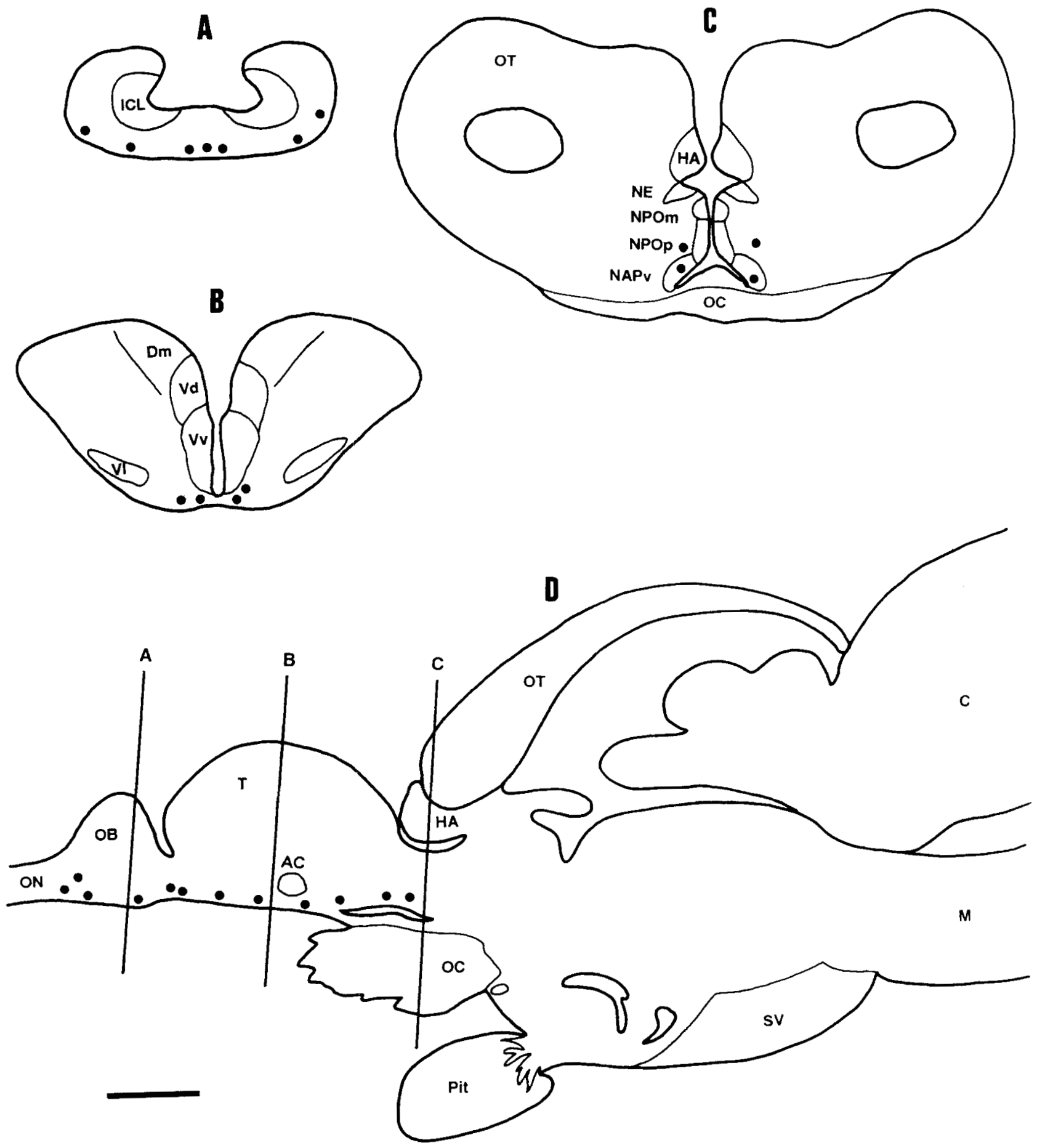

Fig. 4. Distribution of $\mathrm{sGnRH}$ mRNA-containing perikarya revealed by in situ hybridization in the brain of rainbow trout. Frontal sections at the level of the olfactory bulbs (A), telencephalon $(\mathbf{B})$, and preoptic area $(\mathbf{C})$ and overall representation in the sagittal plane $(\mathbf{D})$. Scale bar $=1 \mathrm{~mm}$.

fibers and some ir cell bodies were also observed into the medial forebrain bundle.

Most of the ir cells observed in the preoptic area were located in the ventral parts of NPP and NPOp (Fig. 7D), but some ir cells were also observed in the lateral part of NAPv. These preoptic ir neurons were located near the ventral surface of the superior wall of the preoptic recess. Most of them were bipolar, fusiform, and oriented rostrocaudally.

A light brown labeling was also observed in preoptic magnocellular cells (Fig. 7G). The coloring was less intense and appeared to be blurred; it was different from that seen in the other structures, but, because it disappeared after 

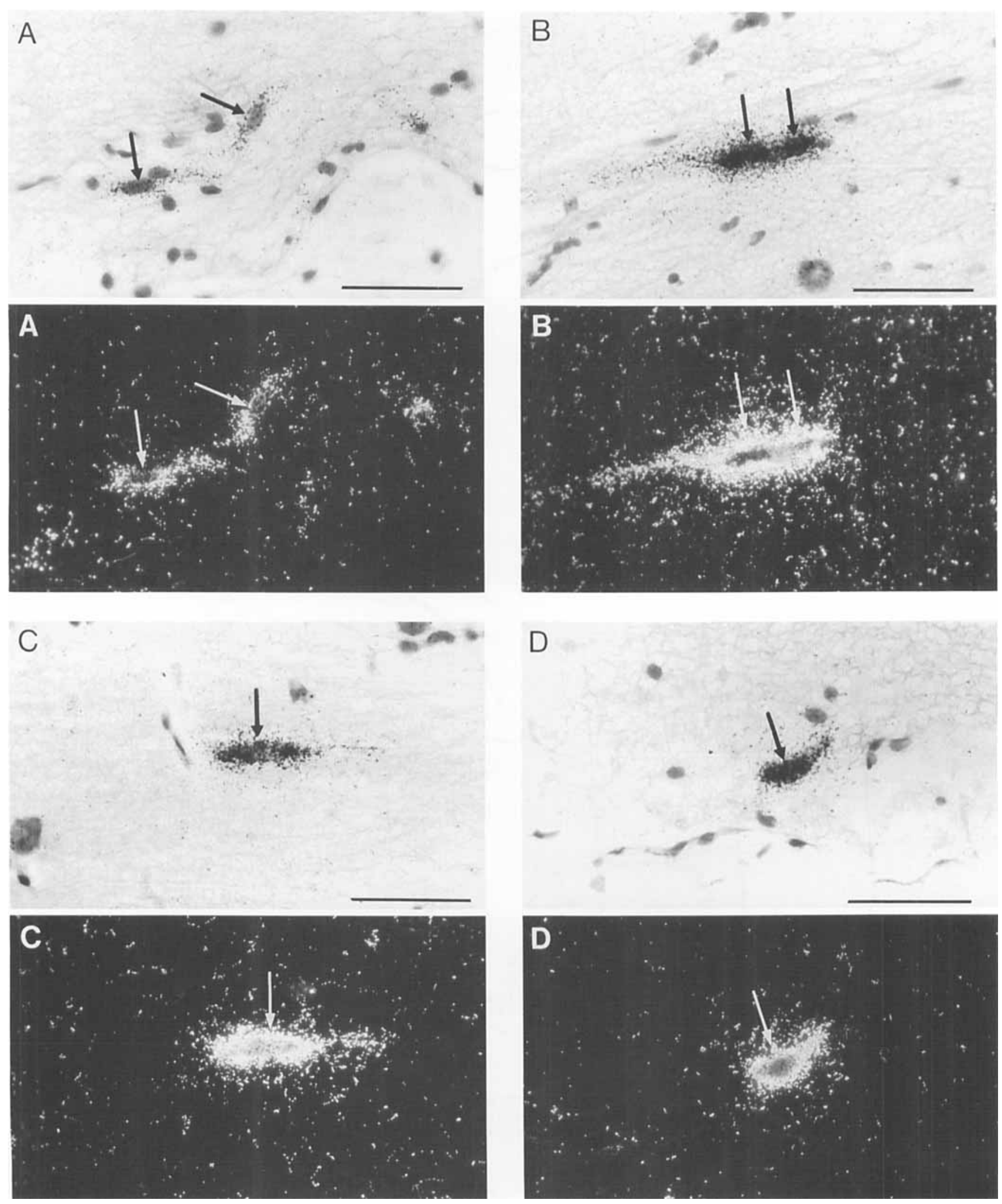

Fig. 5. Brightfield (top) and darkfield (bottom) photomicrographs of sGnRH mRNA-containing cells in rainbow trout. Labeled cell bodies (arrows) were observed in the olfactory bulbs (A), telencephalon (B,C), and ventral preoptic area $(\mathbf{D})$. Scale bar $=50 \mu \mathrm{m}$. 


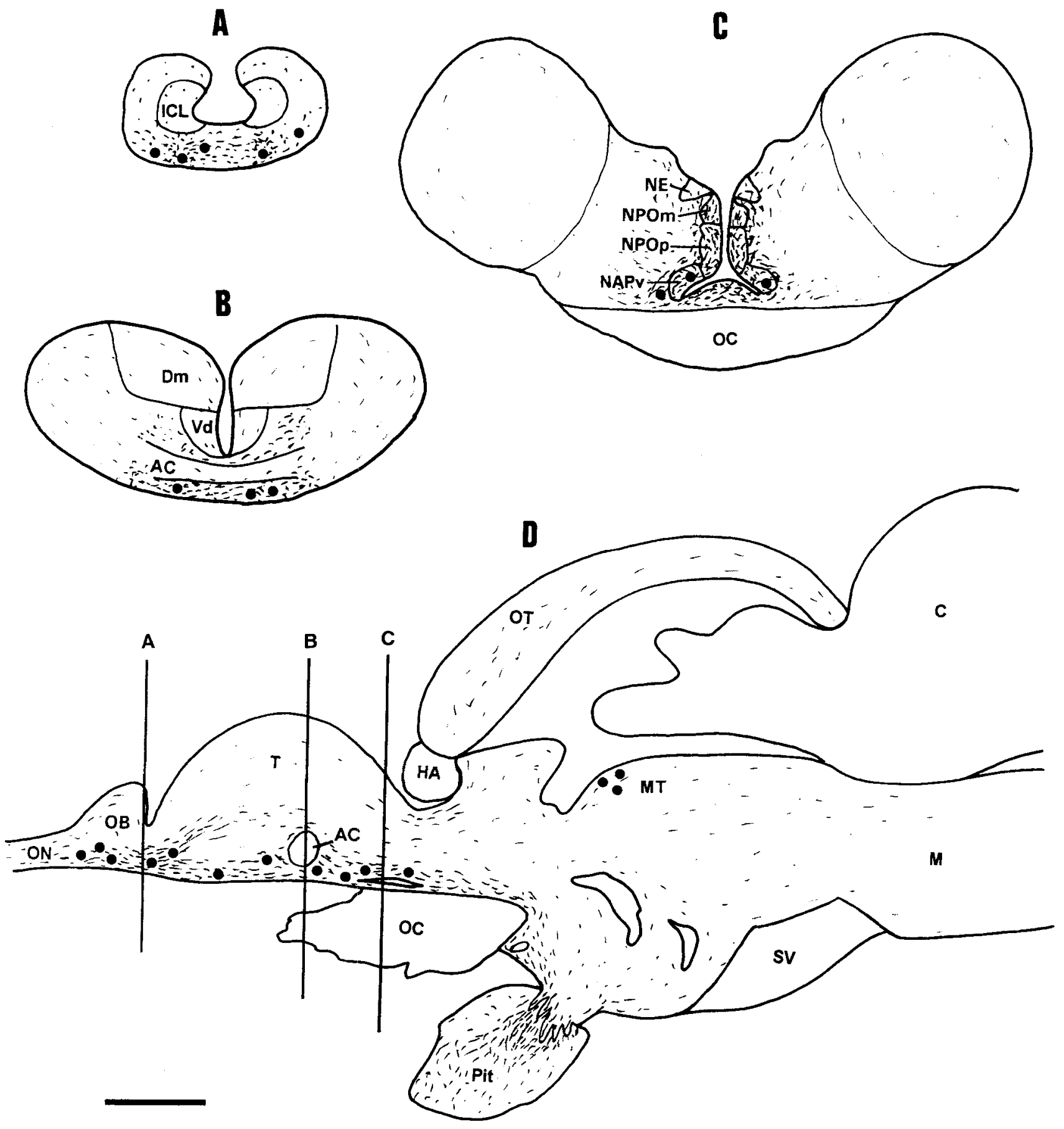

Fig. 6. Distribution in the frontal (A-C) and sagittal (D) plane of SGnRH-ir cell bodies (solid circles) and fibers (short lines) in the brain of rainbow trout. Scale bar $=\mathbf{1} \mathbf{m m}$.

preadsorption of the antiserum with synthetic sGnRH, it was considered to be a specific staining.

A cluster of ir neurons was also identified in MT. They were also elongated in shape but were oriented dorsoventrally, perpendicular to the ventricular wall (Fig. 7H,I). Staining in these cells was less intense than in the telencephalic neurons, but it disappeared after preabsorption of the antiserum with synthetic sGnRH.
Immunoreactive fibers were observed everywhere in the brain. However, fiber density was higher in the structures that contained ir perikarya, namely, the olfactory bulbs, ventral telencephalon, and preoptic area (Fig. $7 \mathrm{~A}-\mathrm{E}$ ). We also observed a high density of ir fibers in the ventral hypothalamus (Fig. 7F) and in the digitations of the neurohypophysis that penetrate the proximal pars distalis of the pituitary. 

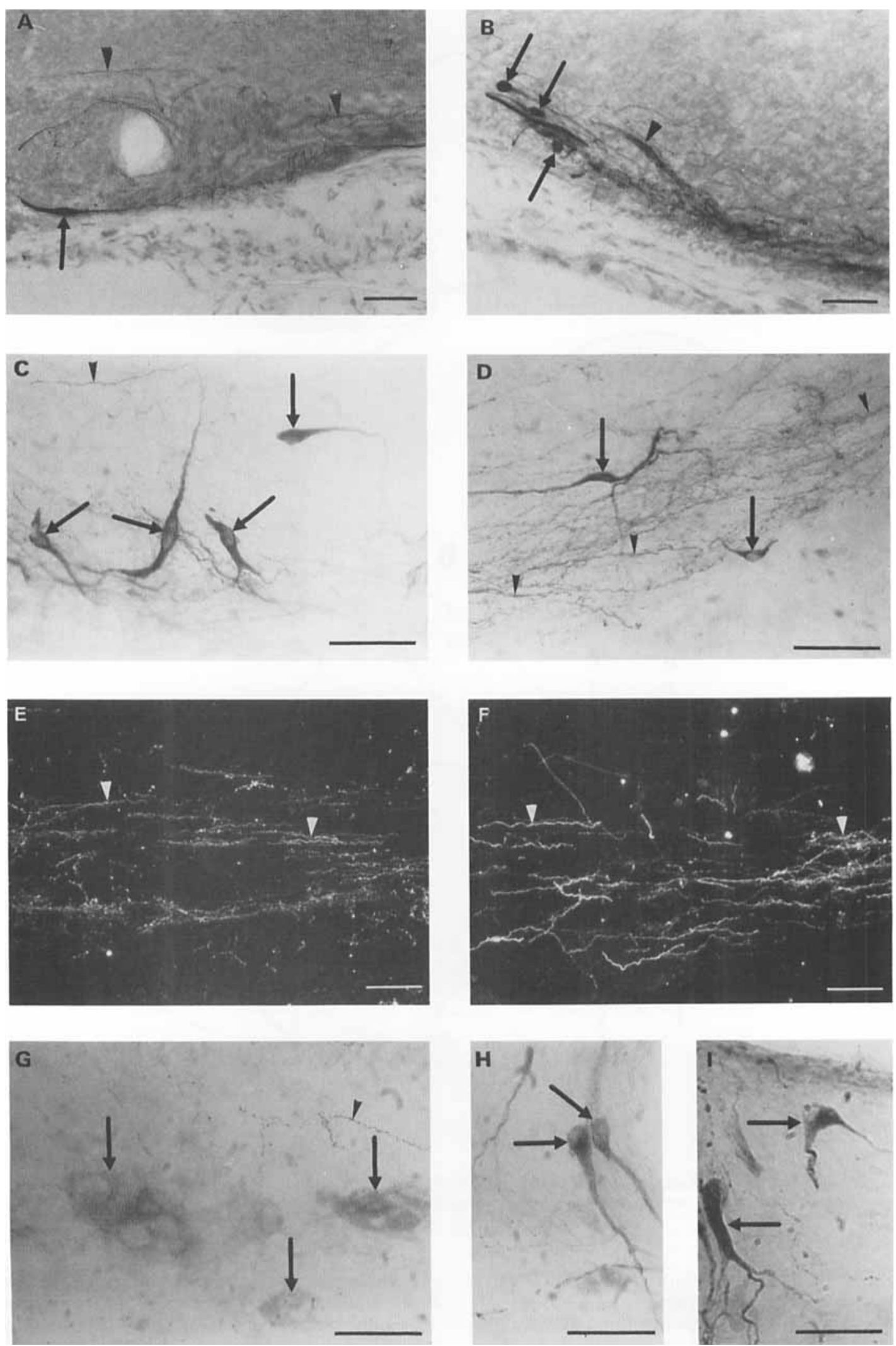

Fig. 7. Brightfield (A-D, G-I) and darkfield (E,F) photomicrographs of sGnRH-ir neurons in the brain of rainbow trout. Ir cell bodies (arrows) were observed in the olfactory bulbs (A), telencephalon (B,C), ventral preoptic area (D), NPOm (G), and MT (H,I) Fibers (arrowheads) were widely distributed in all these structures, including the preoptic area $(\mathrm{E})$ and hypothalamus $(\mathrm{F})$. Scale bar $=50 \mu \mathrm{m}$. 


\section{DISCUSSION}

Our study was conducted on female Atlantic salmon and rainbow trout that had reached the last stage of vitellogenesis because it has been found in two other salmonid species (brown trout and masu salmon) that the level of sGnRH in the brain increases during this period, suggesting a strong synthesis activity (Breton et al., 1986; Amano et al., 1992). A similar increase was observed in male Atlantic salmon, but to a much lesser extent (Amano et al., 1993).

Because of the high degree of conservation of the sequence of salmonid GnRH mRNAs (Klungland et al., 1992a), it was possible to use the Atlantic salmon cDNA probe for hybridization studies in both species. From the Northern blot hybridization of telencephalic mRNA, it appears that the rainbow trout $\mathrm{sGnRH}$ messenger is about 500 bases long, which is close in length to that found in Atlantic salmon (Klungland et al., 1992b) or masu salmon (Suzuki et al., 1992).

In both species, in situ hybridization was performed under high-stringency conditions. Under these conditions, the control sense probe generated a low and homogenous background. The specific signal obtained with the antisense probe was strong in cell bodies that were thought to be sGnRH-expressing perikarya. By contrast, the signals were weak and similar to the control background in the rest of tissues.

The distribution of sGnRH-expressing neurons as revealed by in situ hybridization was similar in the two salmonids and agreed with the data of Suzuki et al. (1992) obtained in the masu salmon. Apart from two structures, NPOm and MT, results from in situ hybridization were very close to those obtained from immunocytochemistry.

Several studies published earlier have given apparently conflicting results. One disagreement is that preoptic magnocellular neurons were reported to be specifically stained by immunocytochemistry for sGnRH in the masu salmon (Amano et al., 1991) and the rainbow trout (Shäffer et al., 1989) but were not always immunoreactive in the present study. Because in both salmonids these cells were not labeled by in situ hybridization, we have concluded that they do not express sGnRH. Positive immunostaining of these neurons could result from nonspecific reactions but could also indicate the presence of GnRH peptide in cells where the gene is not expressed. In a previous study (Bailhache et al., 1989), we found sGnRH-sensitive neurons in the preoptic nucleus, suggesting the presence of sGnRH receptors in this area. Thus it is likely that sGnRH-receptor complexes were fixed in this structure during the fixation step and could subsequently be detected by immunocytochemistry. This procedure has already been used in mammals to study mGnRH-receptor complex (Stenberger, 1978). Therefore, the staining in NPOm could be dependent on the releasing activity of $\mathrm{GnRH}$ neurons projecting to the preoptic area.

Some authors have also described a cluster of $\mathrm{GnRH}$ cell bodies in the tegmentum of the midbrain in several teleost species using anti-mGnRH antibodies (Kah et al., 1989; Coe et al., 1992). Cell bodies in this area were stained with anti-sGnRH antibody, but none was labeled by in situ hybridization. This is consistent with the data of Amano et al. (1991) in the masu salmon, suggesting that these cells are likely to be cGnRH-II neurons. A similar group of cGnRH II neurons was first described in the Japanese quail and the domestic fowl (Mikami et al., 1988).
By contrast, sGnRH cell bodies that were found in the basal hypothalamus of several species, including goldfish (Kah et al., 1984, 1986), European eel (Kah et al., 1989), and platyfish (Münz et al., 1981; Schreibman et al., 1983), were not present in the rainbow trout and Atlantic salmon.

Previous data from immunocytochemistry of the $\mathrm{GnRH}$ in the rainbow trout were inconsistent and contradictory (Goos and Murathanoglu, 1977; Dubois et al., 1979; Shäffer et al., 1989). The GnRH systems described by these authors were all different despite the fact that they used antisera directed against $\mathrm{mGnRH}$. This, in fact, could explain the discrepancy, because these antisera probably had different cross-reactivities with the two GnRHs present in the rainbow trout brain. Conflicting results were also obtained in the goldfish: Its GnRH system was first described using an anti-mGnRH antiserum (Kah et al., 1984) and was later reinvestigated with an anti-sGnRH antiserum (Kah et al., 1986). Studying the rainbow trout, Shäffer et al. (1989) used either the anti-mGnRH or our anti-sGnRH, but their results still differ from ours. This can be explained by the different procedures used for fixation and embedding, which might lead to a loss of sensitivity.

However, our results from in situ hybridization and immunocytochemistry are in agreement with most of the studies performed previously in other salmonids, brown trout (Breton et al., 1986), masu salmon (Amano et al., 1991; Suzuki et al., 1992) or other teleost species, platyfish (Münz et al., 1981; Schreibman et al., 1983), catfish (Goos et al., 1985), Japanese eel (Nozaki et al., 1985), and sole (Nunez Rodriguez et al., 1985). As in many vertebrates (Muske, 1993), GnRH neurons of the olfactory bulbs and rostral telencephalon appear to belong to the terminal nerve. They probably represent part of a migratory pathway from the olfactory placode to the basal forebrain, as demonstrated for the GnRH cells in amphibians, birds, and mammals (Schwanzel-Fukuda and Pfaff, 1991).

By the use of two complementary techniques, our study not only gives a precise distribution of the sGnRH system in two salmonids but rectifies the ambiguous data previously published for rainbow trout.

\section{ACKNOWLEDGMENTS}

We are grateful to Mrs. J. Chauvin and M. Marmignon for their help in histology and typing, respectively, and also to $\mathrm{Mr}$ L. Communier for photomicrographs. We thank Dr. A. Bourdeau for her help with proofreading.

\section{LITERATURE CITED}

Amano, M., Y. Oka, K. Aida, N. Okumoto, S. Kawashima, and Y. Hasegawa (1991) Immunocytochemical demonstration of salmon $\mathrm{GnRH}$ and chicken GnRH-II in the brain of masu salmon, Oncorhynchus masou. J. Comp. Neurol. 314:587-597.

Amano, M., K. Aida, N. Okumoto, and Y. Hasegawa (1992) Changes in salmon GnRH and chicken GnRH-II contents in the brain and pituitary, and GTH contents in the pituitary in female masu salmon, Oncorhyn chus masou, from hatching through ovulation. Zool. Sci. 9:375-386.

Amano, M., K. Aida, N. Okumoto, and Y. Hasegawa (1993) Changes in levels of $\mathrm{GnRH}$ in the brain and pituitary and GTH in the pituitary in male masu salmon, Oncorhynchus masou, from hatching through maturation. Fish Physiol. Biochem. 11:233-240.

Angerer, L.M., and R.C. Angerer (1981) Detection of poly(A+)RNA in sea urchin eggs and embryos by quantitative in situ hybridization. Nucleic Acids Res. 9:2819-2840.

Auffray, C., and F. Rougeon (1980) Purification of mouse immunoglobulin heavy-chain messenger RNAs form total myeloma tumor RNA. Eur. J. Biochem. 107:303-314 
Aviv, H., and P. Leder (1972) Purification of biologically active globin messenger RNA by chromatography on oligothymidylic acid-cellulose. Proc. Natl. Acad. Sci. USA 69:1408-1412.

Bailhache, T., G. Salbert, J.C. Guillet, C. Saligaut, B. Breton, and P. Jego (1989) A new perifusion method adapted to rainbow trout (Salmo gairdneri) brain pituitary preparation for simultaneous electrophysiological recording and hormone secretion determination. Comp. Biochem. Physiol. (A) 94:305-313.

Billard, R., and R.E. Peter (1982) A stereotaxic atlas and technique for nuclei of the diencephalon of rainbow trout (Salmo gairdneri). Reprod. Nutr. Dev. $22: 1-25$.

Breton, B., A. Motin, O. Kah, F. Lemenn, S. Geoffre, G. Precignoux, and P. Chambolle (1984) Dosage radioimmunologique homologue d'un facteur hypothalamique de stimulation de la fonction gonadotrope hypophysaire de saumon sGnRH. C.R. Acad. Sci. Série III 299:383-388.

Breton, B., A. Motin, R. Billard, O. Kah, S. Geoffre, and G. Precignoux (1986) Immunoreactive gonadotropin-releasing hormone-like material in brain and the pituitary gland during the periovulatory period in the brown trout (Salmo trutta L.): Relationships with the plasma and pituitary gonadotropin. Gen. Comp. Endocrinol. 61:109-119.

Coe, I.R., H.J. Grier, and N.M. Sherwood (1992) Gonadotropin-releasing hormone in the molly Poecilia latipinna: Molecular form, quantity, and location. J. Exp. Zool. 261:414-423.

Cox, K.H., D.V. Deleon, L.M. Angerer, and R.C. Angerer (1984) Detection of mRNAs in sea urchin embryos by in situ hybridization using asymmetric RNA probes. Dev. Biol. 101:485-502.

Dubois, M.P., R. Billard, B. Breton, and R.E. Peter (1979) Comparative distribution of somatostatine, LH-RH, neurophysin and $\alpha$-endorphin in the rainbow trout: An immunocytological study. Gen. Comp. Endocrinol. 37:220-232.

Goos, H.J.T., and O. Murathanoglu (1977) Localization of gonadotropinreleasing hormone (GRH) in the forebrain and neurohypophysis of the trout (Salmo gairdneri). Cell Tissue Res. 181:163-168.

Goos, H.J.T., R. De Leeuw, C. De Zoeten-Kamp, J. Peute, and S. Blähser (1985) Gonadotropin-releasing hormone-immunoreactive neuronal structures in the brain and pituitary of the African catfish, Clarias gariepinus (Burchell). Cell Tissue Res. 241:539-596.

Kah, O., P. Chambolle, P. Dubourg, and M.P. Dubois (1984) Immunocytochemical localisation of luteinizing hormone-releasing hormone in the brain of the goldfish Carassius auratus. Gen. Comp. Endocrinol. 53:107115.

Kah, O., B. Breton, J.G. Dulka, J. Nunez-Rodriguez, R.E. Peter, A. Corrigan, J.E. Rivier, and W.W. Vale (1986) A reinvestigation of the GnRH (gonadotropin-releasing hormone) systems in the goldfish brain using antibodies to salmon GnRH. Cell Tissue Res. 244:327-337.

Kah, O., S. Dufour, S. Baloche, and B. Breton (1989) The GnRH systems in the brain and pituitary of normal and hCG treated European silver eels Fish Physiol. Biochem. 6:279-284.

Klungland, H., $\varnothing$. Andersen, and P. Alestrøm (1992a) The salmon gonadotropin-releasing hormone encoding gene in salmonids. Mol. Mar. Biol Biotechnol. 1:420-425.

Klungland, H., J.B. Lorens, Ø. Andersen, G.Ø. Kisen, and P. Alestrøm (1992b) The Atlantic salmon prepro-gonadotropin releasing hormone gene and mRNA. Mol. Cell. Endocrinol. 84:167-174.

Mikami, S., S. Yamada, Y. Hasegawa, and K. Miyamoto (1988) Localization of avian LHRH-immunoreactive neurons in the hypothalamus of the domestic fowl, Gallus domesticus, and the Japanese quail, Coturnix coturnix. Cell. Tissue Res. 251:51-58.

Münz, H. W.E. Stunpf, and L. Jennes (1981) LHRH systems in the brain of platyfish. Brain Res. 221:1-13.

Muske, L.E. (1993) Evolution of gonadotropin-releasing hormone (GnRH) neuronal systems. Brain Behav. Evol. 42:215-230.
Nozaki, M., I. Fujita, N. Saito, T. Tsukahara, H. Kobayashi, K. Ueda, and K. Oshima (1985) Distribution of LHRH-like immunoreactivity in the brain of the Japanese eel (Anguilla japonica) with special reference to the nervus terminalis. Zool. Sci. 2:537-547.

Nunez Rodriguez, J., O. Kah, B. Breton, and F. Le Menn (1985) Immunocytochemical localization of GnRH (gonadotropin releasing hormone) systems in the brian of a marine teleost fish, the sole. Experientia 41:1574-1576.

Okuzawa, K., M. Amano, M. Kobayashi, K. Aida, I. Hanyu, Y. Hasegawa, and K. Miyamoto (1990) Differences in salmon GnRH and chicken GnRH-II contents in discrete brain areas of male and female rainbow trout according to age and stage of maturity. Gen. Comp. Endocrinol 80:116126.

Peter, R.E., and J.N. Fryer (1983) Endocrine functions of the hypothalamus of Actinopterygians. In R.E Davis and R.G. Northcutt (eds): Fish Neurobiology, Vol. II, Ann Arbor, MI: University of Michigan Press, pp. 165-201.

Salbert, G., G. Bonnec, P. Le Goff, D. Boujard, Y. Valotaire, and P. Jego (1991) Localization of the estradiol receptor mRNA in the forebrain of the rainbow trout. Mol. Cell. Endocrinol. 76:173-180.

Schäfer, H., R. Schutz, and V. Blüm (1989) Immunoreactivity to gonadotropin-releasing hormone and gonadotropic hormone in the brain and pituitary of rainbow trout Salmo gairdneri. Cell Tissue Res. 257:227235.

Sehreibman, M.P., L. Halpern-Sebold, M. Ferin, H. Margolis-Kazan, and H.J.T. Goos (1983) The effect of hypophysectomy and gonadotropin administration on the distribution and quantity of LH-RH in the brains of platyfish: A combined immunocytochemistry and radioimmunoassay study. Brain Res. 267:293-300.

Schwanzel-Fukuda, M., and D.W. Pfaff (1991) Migration of LHRHimmunoreactive neurons from the olfactory placode rationalizes olfactohormonal relationships. J. Steroid Biochem. Mol. Biol. 39:565-572.

Sherwood, N.M., L. Eiden, M. Brownstein, J. Spiess, J. Rivier, and W.W. Vale (1983) Characterization of a teleost Gn-RH. Proc. Natl. Acad. Sci. USA 80:2794-2798.

Sherwood, N.M., B. Harvey, M.J. Brownstein, and L.E. Eiden (1984) Gonadotropin-releasing hormone (Gn-RH) in striped mullet (Mugil cephalus), milkfish (Chanos chanos) and rainbow trout (Salmo gairdneri): Comparison with salmon Gn-RH. Gen. Comp. Endocrinol. 55:174181

Sherwood, N.M., R.T. Zoeller, and F.L. Moore (1986) Multiple forms of gonadotropin-releasing hormone in amphibian brain. Gen. Comp. Endocrinol. 61:313-322.

Sower, S.A., Y.C. Chiang, S. Lovas, and J.M. Conlon (1993) Primary structure and biological activity of a third gonadotropin-releasing hormone from lamprey brain. Endocrinology 132:1125-1131.

Sternberger, L.A., J.P. Petrali, S.A. Joseph, H.G. Meyer, and K.R. Mills (1978) Specificity of the immunochemical luteinizing hormone-releasing hormone receptor reaction. Endocrinology 102:63-73.

Suzuki, M., S Hyodo., M. Kobayashi, K. Aida, and A. Urano (1992) Characterization and localization of mRNA encoding the salmon type gonadotropin-releasing hormone precursor of the masu salmon. J. Mol. Endocrinol 9:73-82.

Thomas, P.S. (1980) Hybridization of denatured RNA and small DNA fragments transferred to nitrocellulose. Proc. Natl. Acad. Sci. USA 77:5201-5205.

Wilkinson, D.G., J.A. Bailes, J.E. Champion, and A.P. McMahon (1987) A molecular analysis of mouse development from 8 to 10 days post coitum detects changes only in embryonic globin expression. Development 99:493-500. 